\title{
The Effect of IELTS Listening Strategy Use on the Reduction of IELTS Listening Test Anxiety and on IELTS Listening Performance
}

\author{
Amir Reza Nemat Tabrizi \\ Department of English Language, Payame Noor University, I. R. of Iran \\ Mahnaz Ranjbar \\ Islamic Azad University, Ahar, Iran
}

\begin{abstract}
The study investigates the impact of IELTS listening strategy use on the reduction of listening test anxiety and on the listening performance of the IELTS test takers in light of the data of 80 participants on the pretest and post-test IELTS listening along with the participants' score on pre-anxiety and post anxiety scale. So, drawing on the instruments including a proficiency test, pre/post-test, anxiety questionnaire, materials for strategy instruction, the participants were randomly divided into two groups: Control Group and Experimental Group, each including 40 participants. As per the procedure, after tackling their pre-listening performance and pre-anxiety score, one group was treated with IELTS-Listening related strategies and the other group was not treated, but both were administered listening test. The results of the study indicated that those treated with IELTS strategy outperformed $(t(78)=4.57, p=.000, r=.460)$ those receiving no listeningrelated strategy. Furthermore, the results of a t-test run on the post-test of the groups anxiety arrived at a statistically significant difference $(t)(78)=5.77, p=.000, r=.547)$, representing that the control group outperformed the experimental group. Also, Pearson Correlation done for finding out a potential relationship between anxiety and listening performance indicated a negative and weak to moderate relationship $((\mathbf{r})(78)=$ $.26, p=.020)$. The pedagogical implications of the study are in detailed argued.
\end{abstract}

Index Terms-IELTS, strategy use, anxiety, anxiety reduction

\section{INTRODUCTION}

For many years, listening skill did not receive any attention in language teaching, so that teaching methods focused only on productive skills rather than on the receptive ones, i.e., listening, and the relationship between productive and receptive skills was not noticeable or was poorly regarded (Rishards \& Renandya, 2002). Therefore, as they state, until recently, the application of listening was neglected; it was often thought that listening is not needed to be instructed. Listening is a crucial skill for second language (L2) learners and has received substantial attention in L2 assessment literature (e.g., Aryadoust, 2013), but it is the least examined skill in L2 assessment literature (Lynch, 2011).

In support of the note made, Carter and Nunan (2001) state that listening in language teaching has too much changed, as the result of developments in anthropology, education, linguistics, sociology, and global politics. They follow to trace the significance of listening during the late nineteenth century Reform Movement, so that the accuracy of perception and the clarity of auditory memory became focal language learning skill, then several models for listening have appeared.

Present models explain the complex nature of L2 listening comprehension as a set of cognitive processes needed for perceiving and building meaning, and interpreting the message by establishing its relevance to the social context as well as determining its communicative function (Vandergrift, 2007). This understanding of L2 listening structure, however, does not lead to a definite definition of a listening construct that would in general welcomed by the majority of L2 assessment experts; thus, when a listening test is designed, it becomes the test developer's responsibility to provide a definition to it, as L2 listening test engages the required cognitive processes (Vandergrift \& Tafaghodtari, 2010).

However listening is a receptive skill, this does not carry the sense that it is a passive skill, because the listener can be either passive or active (Lindsay \& Knight, 2006). They continue with their explanation that when we are in a conversation, we listen, respond appropriately, and sometimes stop the conversation to ask the speakers as to the produced message. This means that the listeners are involved in the process of decoding the message. This is what is called active listening because the listeners have some control of what they are listening to (Richards \& Renandya, 2002; Carter \& Nunan, 2001).

In a setting associated with foreign language learning, the learners learn through the medium of formal instruction with little exposure to the language input outside the learning context. The learners' ability to comprehend spoken input is limited and a vast variety of factors associated with affective elements, such as anxiety, influence the learners' oral proficiency and performance (Chen \& Chang, 2004). Some researchers (e.g., Xu, 2011; Liu, 2006; In'nami, 2006; 
Moyer, 2006) argue that one of the skills affected by affective elements, i.e., anxiety, is listening, which had been neglected in the L2 literature until recently: A deep investigation into the history of language learning reveals this lack of attention to the skill of listening. They follow that the neglect of the listening skill was in line with the debate that which of the four language skills (speaking, listening, reading, and writing) is deemed significant. According to them, research so far proves the listening skill to be the most important skill for language learning due to the fact that it is the most globally used language skill in everyday life. Persisting on the significance of the listening skill, they are on the status that listening skill can facilitate the process of other language skill development (Cassady, \& Johnson, 2001; Ching-Shyang Chang, \& Read, 2006; Elkhafaifi, 2005; Goh, 2008; Yeldha \& Gruba, 2014).

By definition, the mental processes on which listeners use to understand, learn, or to retain new information from the aural input are related to listening comprehension strategies (Yeldha \& Gruba, 2014). As they follow, pevious L2 listening research revealed that learners need to develop certain listening strategies that help them capitalize on the oral language input they are receiving and overcome those difficulties. These strategies are classified into three main types: cognitive, metacognitive, and socio-affective strategies (Goh, 2008; Richards \& Renandya, 2002; Swan, 2008). When learners were taught those strategies, their listening performance has considerably improved. L2 listening research has also showed that more-skilled learners tend to rely on a repertoire of strategies to regulate their listening processes. Not only do they employ more metacognitive strategies than their less-skilled learners (Goh, 2008).

Furthermore, listening strategies, in addition to developing listening comprehension ablity, can also help the language learners cope with listening anxiety. Bachman and Palmer (1996) are on the position that emotional elements exert their own effect on the performance of the learners. Plenty of researchers (Bachman, 1995; Bachman \& Palmer, 1996; Dunkel, 1991), hold the view that lots of factors can affect the test takers' performance, such as the setting, the input text, the speaker, the test-taker and the response task.

The present study does not happen in the vacuum, rather it happens in the context of IELTS; to be more brief about IELTS, it is anecdotal as well as well-documented that IELTS took the place of the earlier English Language Testing Service (ELTS); it was first understood in 1976 and was then introduced in 1980 by the British Council; the ELTS test was originally designed as a test for prospective postgraduate students, but there was a growing demand from other student groups and institutions, especially in Australia (IELTS Annual Review, 2007); it is argued that, nowadays, there lies more need to this international test, i.e., IELTS, so that USA also said YES to IELTS. In the review of literature, more explanation will be explained on IELTS. Since the thesis is on strategy use and test anxiety, a lot of factors pose difficulty for the listeners; these factors include unfamiliar vocabulary and topic, speed of speech, and unfamiliar accents. It should be also noted that in intensive listening, the listeners hear the spoken language only once so that this provides limited opportunity for the listeners to process the information in short time (Goh, 2008; In'nami, 2006; Liu, 2006); this can put the listeners under pressure and hence lead to anxiety. To compensate for this, some strategies are needed to overcome the problem. In the current study, thus, strategy use is considered to be seen either it reduces the listening anxiety or not (Cross, 2009). Therefore, for the purposes of the current study, listening comprehension ability is the ability to understand and process a realistic spoken language happening in real time (Jakeman \& McDowell, 2006). But, to do the study, the aim is to see that either IELTS listening anxiety will be reduced with a view to strategy use or not and that either strategy instruction affects the performance of the groups or not. Therefore, the following research questions are investigated.

1. Does IELTS-Listening-related strategy instruction reduce the IELTS-listening-related anxiety of the test takers?

2. Does IELTS-Listening-related strategy instruction develop the performance of the IELTS listening test takers?

3. Is there any relationship between the performance of the group with high anxiety and a group with low anxiety on IELTS listening test?

\section{METHODOLOGY}

\section{Participants}

The participants in the study were 90 EFL learners; in reality, out of the whole population of 90,80 participants divided into two groups of experimental and control- were asked for participation, taking an IELTS preparation course at Iranian English Language Institute in Ardebil. The learners, randomly selected, were English language learners at upper-intermediate and advanced level, which were specified with use of a listening proficiency test. Added to that, the learners were selected to be high school students, ranging at age from 15-20, attending the mentioned center for approximately three years and for the purpose of attending IELTS class.

\section{Instruments}

In the present study, the following instruments will be employed:

1. An anxiety questionnaire associated with listening (Innami, 2006; Xu, 2011) was adopted and adapted and the reliability of which was also examined with use of Cranbach Alpha. The questionnaire was in likert-type form, i.e., agree, strongly agree, disagree, strongly disagree and neutral, numbered1, 2, 3, 4 and 5, respectively; totally, 22 statements was included in the test.

2. Listening-strategy-related materials associated with IELTS listening (McCarter, 2006; Jakeman \& McDowell, 2006) - 10 common strategies - were employed for instructing the experimental group. 
3. The pre-test and post-test, both being a form of the IELTS listening (Cambridge University, 2005) and including 40 questions were used in the present study. In effect, both post-test and pre-test were IELTS listening tests administered to IELTS applicants in mock test situation.

\section{Procedure and Design}

To do the present study, the following procedures were considered; first of all, an anxiety questionnaire- a selfdeveloped questionnaire adopted from the work of two researchers (adapted and adopted from Innami, 2006; Xu, 2011) was administered to 90 learners and based on their score, 80 learners were randomly selected and assigned into two groups of 40, i.e., experimental group with 40 learners and control group with 40 learners; both groups were first given one similar anxiety questionnaire before treatment. Second, both groups' listening knowledge was pre-tested with one IELTS listening proficiency test (Cambridge IELTS, 2005) to assess their entry performance which needed a t-test; this was done for the objectives of the pre-test performance of the groups with their post-performance. Given this procedure, their pre-anxiety test performance and their pre-listening performance were recorded for analysis. Then, both groups were given 10 tests of IELTS listening in 10 sessions, every session one test: every session lasting for 50 minutes; during this 50 minutes, the experimental group was given, taught and explained strategy hand-out, i.e., treatment, associated with IELTS listening strategies, but the control group was not given, taught and instructed strategy hand-out. After collecting their score on post-anxiety questionnaire, they were given one final listening test including 40 questions in 30 minutes. In the end, the post-anxiety and post-listening of experimental and control groups were compared. Also, the relationship between their anxiety and their listening performance were found out in the study.

The schematic representation of the procedure and design appears below:

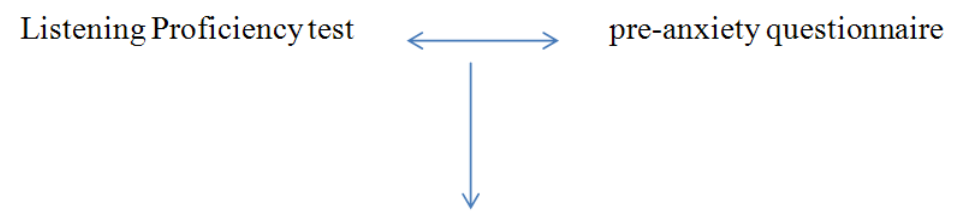

Administration of 10 tests to both groups in 10 sessions

(Every session lasting for 50 minutes)

Treatment on listening strategy just for experimental group

(Control group was not treated listening strategy)

Administration of post-listening to both groups

\section{Data Collection and Data Analysis}

The data for the present study were collected at Iranian Institute of English language including two branches in Ardebil Province, Iran. The required data were collected from the performance of 90 participants. With respect to data analysis, the homogeneity of the subjects was proved by ANOVA and then t-test and Pearson Correlation were used; a t-test was used for the purpose of analyzing the data associated with experimental and control groups' performance on the post-anxiety and post-listening and Pearson Correlation was used for finding the relationship between their anxiety and listening performance.

\section{RESUlTS AND ANALYSIS}

To start the analysis, first, the present data were analyzed through independent-samples t-test and Pearson correlation, both of which assume normality of the data.

TABLE 1

DESCRIPTIVE STATISTICS; TESTING NORMALITY OF DATA

\begin{tabular}{lllllllll}
\hline \multirow{3}{*}{ Group } & & $\mathrm{N}$ & \multicolumn{3}{c}{ Skewness } & \multicolumn{3}{c}{ Kurtosis } \\
\cline { 2 - 8 } Experimental & & Statistic & Statistic & Std. Error & Ratio & Statistic & Std. Error Ratio \\
\hline \multirow{4}{*}{ Control } & Pre-Listening & 40 & .273 & .374 & 0.73 & -.469 & .733 & -0.64 \\
& Post-Listening & 40 & -.076 & .374 & -0.20 & -.730 & .733 & -1.00 \\
& Pre-Anxiety & 40 & -.725 & .374 & -1.94 & -.444 & .733 & -0.61 \\
& Post-Anxiety & 40 & -.443 & .374 & -1.18 & -.455 & .733 & -0.62 \\
\hline & Pre-Listening & 40 & .406 & .374 & 1.09 & -.434 & .733 & -0.59 \\
& Post-Listening & 40 & .118 & .374 & 0.32 & -.719 & .733 & -0.98 \\
& Pre-Anxiety & 40 & -.492 & .374 & -1.32 & -.689 & .733 & -0.94 \\
& Post-Anxiety & 40 & -.658 & .374 & -1.76 & -.977 & .733 & -1.33 \\
\hline
\end{tabular}


As displayed in Table 1, the ratios of skewness and kurtosis over their respective standard errors were lower than $+/$ 1.96; hence normality of the data was observed.

\section{Pretest of Listening Proficiency}

As Table 2 indicates, an independent-samples t-test was run to compare the experimental and control groups' performance on the pretest of listening proficiency in order to prove that the two groups were homogenous in terms of their listening ability prior to the administration of the treatment. As displayed in Table 2, the experimental $(\mathrm{M}=24.73$, $\mathrm{SD}=4.39)$ and control $(\mathrm{M}=23.98, \mathrm{SD}=4.01)$ groups had almost the same means on the pretest of listening proficiency.

TABLE 2

DESCRIPTIVE Statistics; Pretest OF Listening ProficienCy By GROUPS

\begin{tabular}{llllll}
\hline & Group & $\mathrm{N}$ & Mean & Std. Deviation & Std. Error Mean \\
\hline \multirow{2}{*}{ Pre-Listening } & Experimental & 40 & 24.73 & 4.391 & .694 \\
& Control & 40 & 23.98 & 4.010 & .634 \\
\hline
\end{tabular}

As it is clear in Table 3 below, the results of the independent-samples t-test $(\mathrm{t}(78)=.798, \mathrm{p}=.427, \mathrm{r}=.090$ representing a weak effect size, $95 \%$ CI $[-1.12,2.62])$ indicated that there was not any significant difference between the experimental and control groups' performance on the pretest of listening proficiency, so the two groups were homogenous.

TABLE 3

INDEPENDENT SAMPLES T-TEST: PRETEST OF LISTENING PROFICIENCY BY GROUPS

\begin{tabular}{|c|c|c|c|c|c|c|c|c|}
\hline & \multicolumn{2}{|c|}{$\begin{array}{l}\text { Levene's Test for Equality of } \\
\text { Variances }\end{array}$} & \multicolumn{6}{|c|}{$\begin{array}{l}\text { t-test for } \\
\text { Equality of Means }\end{array}$} \\
\hline & \multirow[t]{2}{*}{$\mathrm{F}$} & \multirow[t]{2}{*}{ Sig. } & \multirow[t]{2}{*}{ Df } & \multirow{2}{*}{$\begin{array}{l}\text { Sig. }(2- \\
\text { tailed) }\end{array}$} & \multirow{2}{*}{$\begin{array}{l}\text { Mean } \\
\text { Difference }\end{array}$} & \multirow{2}{*}{$\begin{array}{l}\text { Std. Error } \\
\text { Difference }\end{array}$} & \multicolumn{2}{|c|}{$\begin{array}{l}95 \% \text { Confidence Interval of the } \\
\text { Difference }\end{array}$} \\
\hline & & & & & & & Lower & Upper \\
\hline $\begin{array}{l}\text { Equal variances } \\
\text { assumed }\end{array}$ & .406 & .526 & .79878 & .427 & .750 & .940 & -1.122 & 2.622 \\
\hline $\begin{array}{l}\text { Equal variances not } \\
\text { assumed }\end{array}$ & & & .79877 .3 & 4.427 & .750 & .940 & -1.122 & 2.622 \\
\hline
\end{tabular}

The results of the Levene's test $(F=.406, p=.526)$ (Table 3 ) indicated that the assumption of homogeneity of variances was met. That was why the first row of Table 3, i.e. "Equal variances assumed" was reported.

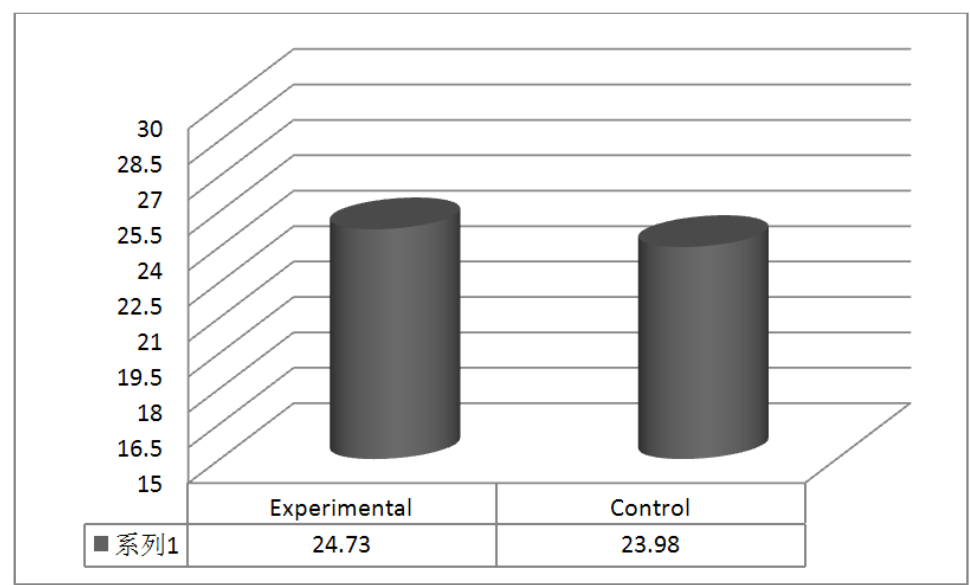

Figure 1. Means on pretest of listening proficiency by groups

\section{Pretest of Listening Anxiety}

According to Table 4, an independent-samples t-test was run to compare the experimental and control groups' means on the pretest of listening anxiety and the result showed that the experimental $(\mathrm{M}=69.45, \mathrm{SD}=8.23)$ and control $(\mathrm{M}=$ $67.83, \mathrm{SD}=8.65$ ) groups had almost the same means on the pretest of listening anxiety.

TABLE 4

DESCRIPTIVE STATISTICS; PRETEST OF LisTENING ANXIETY By GROUPS

\begin{tabular}{llllll}
\hline & Group & $\mathrm{N}$ & Mean & Std. Deviation & Std. Error Mean \\
\hline \multirow{2}{*}{ Pre-Anxiety } & Experimental & 40 & 69.45 & 8.230 & 1.301 \\
& Control & 40 & 67.83 & 8.655 & 1.369 \\
\hline
\end{tabular}

As Table 5 reveals, the results of the independent-samples t-test $(\mathrm{t}(78)=.860, \mathrm{p}=.392, \mathrm{r}=.097$ representing a weak effect size, $95 \%$ CI $[-2.13,5.38])$ indicated that there was not any significant difference between the experimental and control groups' performance on the pretest of listening anxiety. 
TABLE 5

INDEPENDENT SAMPLES T-TEST: PRETEST OF LISTENING ANXIETY BY GROUPS

\begin{tabular}{|c|c|c|c|c|c|c|c|c|}
\hline & \multicolumn{2}{|c|}{$\begin{array}{l}\text { Levene's Test for Equality of } \\
\text { Variances }\end{array}$} & \multicolumn{6}{|c|}{$\begin{array}{l}\text { t-test for } \\
\text { Equality of Means }\end{array}$} \\
\hline & \multirow[t]{2}{*}{$\mathrm{F}$} & \multirow[t]{2}{*}{ Sig. } & \multirow[t]{2}{*}{ Df } & \multirow{2}{*}{$\begin{array}{l}\text { Sig. }(2- \\
\text { tailed) }\end{array}$} & \multirow{2}{*}{$\begin{array}{l}\text { Mean } \\
\text { Difference }\end{array}$} & \multirow{2}{*}{$\begin{array}{l}\text { Std. Error } \\
\text { Difference }\end{array}$} & \multicolumn{2}{|c|}{$\begin{array}{l}95 \% \text { Confidence Interval of the } \\
\text { Difference }\end{array}$} \\
\hline & & & & & & & Lower & Upper \\
\hline $\begin{array}{l}\text { Equal variances } \\
\text { assumed }\end{array}$ & .340 & .561 & .86078 & .392 & 1.625 & 1.889 & -2.135 & 5.385 \\
\hline $\begin{array}{l}\text { Equal variances not } \\
\text { assumed }\end{array}$ & & & .86077 .8 & 3.392 & 1.625 & 1.889 & -2.135 & 5.385 \\
\hline
\end{tabular}

The results of the Levene's test $(\mathrm{F}=.340, \mathrm{p}=.561)$ (Table 5) indicated that the assumption of homogeneity of variances was met. That was why the first row of Table 5, i.e. "Equal variances assumed" was reported.

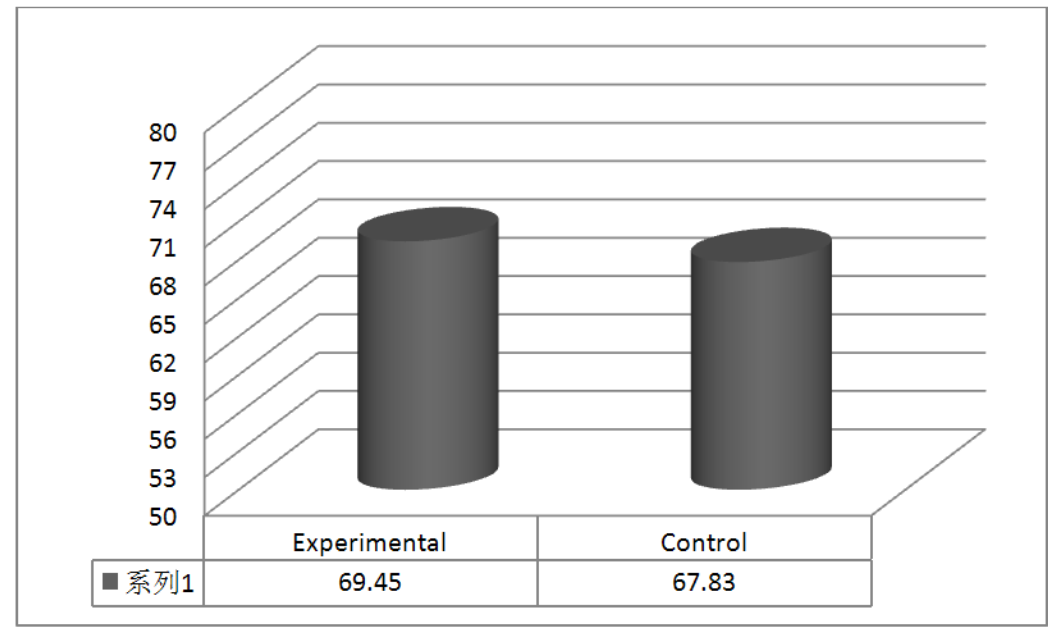

Figure 2. Means on pretest of listening anxiety by groups

\section{The first Research Question}

IELTS-Listening-related strategy instruction does not reduce the IELTS-listening-related anxiety of the test takers. An independent-samples t-test was run to compare the experimental and control groups' means on the posttest of listening anxiety in order to investigate the effect of IELTS-Listening-related strategy instruction on the reduction of their listening anxiety. As displayed in Table 6 , the experimental group $(\mathrm{M}=53.45, \mathrm{SD}=10.79)$ had a lower mean than the control group $(\mathrm{M}=66, \mathrm{SD}=8.51)$ on the posttest of listening anxiety.

TABLE 6

DESCRIPTIVE STATISTICS; POSTTEST OF LISTENING ANXIETY BY GROUPS

\begin{tabular}{llllll}
\hline & Group & $\mathrm{N}$ & Mean & Std. Deviation & Std. Error Mean \\
\hline \multirow{2}{*}{ Post-Anxiety } & Control & 40 & 66.00 & 8.518 & 1.347 \\
& Experimental & 40 & 53.45 & 10.792 & 1.706 \\
\hline
\end{tabular}

The results of the independent-samples t-test $(\mathrm{t}(78)=5.77, \mathrm{p}=.000, \mathrm{r}=.547$ representing a large effect size, $95 \%$ CI $[8.22,16.87])$ (Table 7) indicated that there was a significant difference between the experimental and control groups' performance on the posttest of listening anxiety.

TABLE 7

INDEPENDENT SAMPLES T-TEST: POSTTEST OF LISTENING ANXIETY BY GROUPS

\begin{tabular}{|c|c|c|c|c|c|c|c|c|}
\hline & \multicolumn{2}{|c|}{$\begin{array}{l}\text { Levene's Test for Equality of } \\
\text { Variances }\end{array}$} & \multicolumn{6}{|c|}{$\begin{array}{l}\text { t-test for } \\
\text { Equality of Means }\end{array}$} \\
\hline & \multirow[t]{2}{*}{$\mathrm{F}$} & \multirow[t]{2}{*}{ Sig. } & \multirow[t]{2}{*}{ Df } & \multirow{2}{*}{$\begin{array}{l}\text { Sig. }(2- \\
\text { tailed) }\end{array}$} & \multirow{2}{*}{$\begin{array}{l}\text { Mean } \\
\text { Difference }\end{array}$} & \multirow{2}{*}{$\begin{array}{l}\text { Std. Error } \\
\text { Difference }\end{array}$} & \multicolumn{2}{|c|}{$\begin{array}{l}\text { 95\% Confidence Interval of the } \\
\text { Difference }\end{array}$} \\
\hline & & & & & & & Lower & Upper \\
\hline $\begin{array}{l}\text { Equal variances } \\
\text { assumed }\end{array}$ & 1.604 & .209 & 5.77378 & .000 & 12.550 & 2.174 & 8.222 & 16.878 \\
\hline $\begin{array}{l}\text { Equal variances not } \\
\text { assumed }\end{array}$ & & & 5.77374 & 9.000 & 12.550 & 2.174 & 8.219 & 16.881 \\
\hline
\end{tabular}

The results of the Levene's test $(\mathrm{F}=1.60, \mathrm{p}=.209)$ (Table 7) indicated that the assumption of homogeneity of variances was met. That was why the first row of Table 7, i.e. "Equal variances assumed" was reported. 


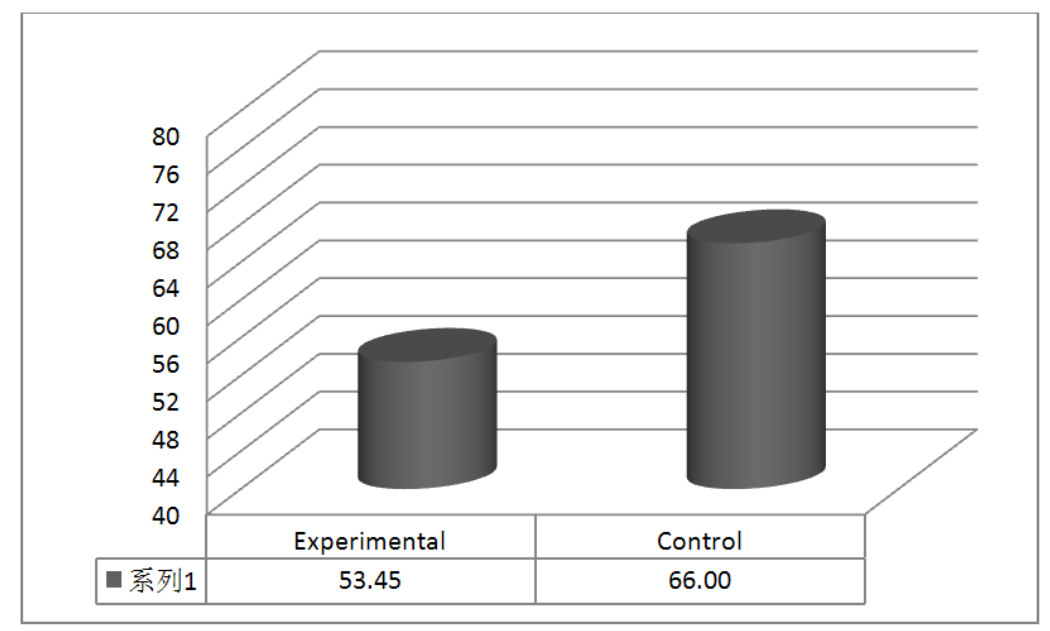

Figure 3. Means on posttest of listening anxiety by groups

\section{Second Research Question}

IELTS-Listening-related strategy instruction does not develop the performance of the IELTS listening test takers. An independent-samples t-test was run to compare the experimental and control groups' performance and as is displayed in Table 9 , the experimental group $(\mathrm{M}=29.60, \mathrm{SD}=4.29)$ had a higher mean than the control group $(\mathrm{M}=25.05, \mathrm{SD}=$ $4.59)$ on the posttest of listening proficiency.

TABLE 9

Descriptive Statistics; PostTest OF Listening ProficienCy By GRoups

\begin{tabular}{llllll}
\hline & Group & $\mathrm{N}$ & Mean & Std. Deviation & Std. Error Mean \\
\hline \multirow{2}{*}{ Post-Listening } & Experimental & 40 & 29.60 & 4.295 & .679 \\
& Control & 40 & 25.05 & 4.596 & .727 \\
\hline
\end{tabular}

The results of the independent-samples t-test $(\mathrm{t}(78)=4.57, \mathrm{p}=.000, \mathrm{r}=.460$ representing an almost large effect size, $95 \%$ CI $[2.57,6.53]$ ) (Table 10) indicated that the experimental group after receiving IELTS-Listening-related strategy instruction significantly outperformed the control group on the posttest of listening proficiency. Thus the second nullhypothesis was rejected.

TABLE 10

INDEPENDENT SAMPLES T-TEST: POSTTEST OF LISTENING PROFICIENCY BY GROUPS

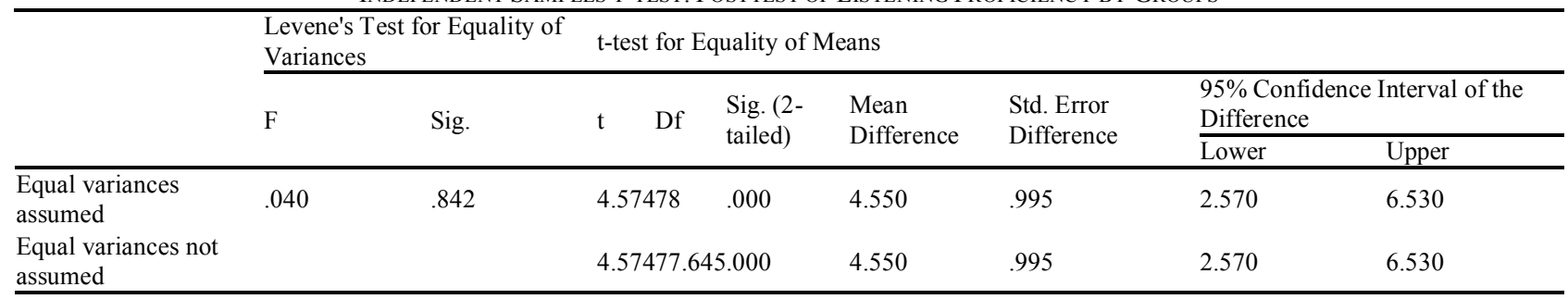

The results of the Levene's test $(\mathrm{F}=.040, \mathrm{p}=.842)$ (Table 10$)$ indicated that the assumption of homogeneity of variances was met. That was why the first row of Table 10, i.e. "Equal variances assumed" was reported. 


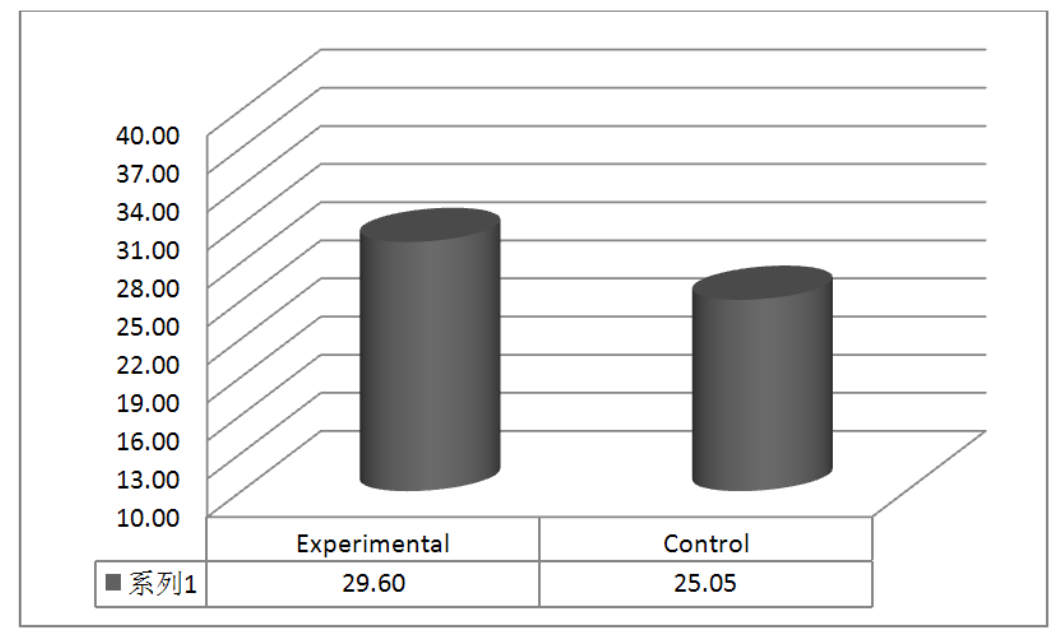

Figure 4. Means on posttest of listening proficiency by groups

\section{Third Research Question}

There is not any relationship between the performance of the group with high anxiety and a group with low anxiety on IELTS listening test. Before discussing the results it should be mentioned that the subjects were divided into two groups of high and low anxiety based on the median score of 32 on the posttest of listening anxiety. Then an independent-samples t-test was run to compare the high and low anxiety groups' performance on the posttest of listening proficiency in order to probe the third null-hypothesis. As displayed in Table 11, the low anxiety group ( $\mathrm{M}=$ $28.21, \mathrm{SD}=4.86)$ had a higher mean than the high anxiety group $(\mathrm{M}=26.49, \mathrm{SD}=5.02)$ on the posttest of listening proficiency.

TABLE 11

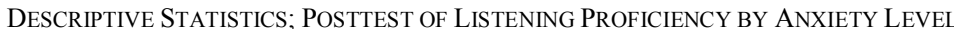

\begin{tabular}{llllll}
\hline & Group & $\mathrm{N}$ & Mean & Std. Deviation & Std. Error Mean \\
\hline \multirow{2}{*}{ Post-Listening } & Low & 39 & 28.21 & 4.841 & .775 \\
& High & 41 & 26.49 & 5.021 & .784 \\
\hline
\end{tabular}

The results of the independent-samples t-test $(\mathrm{t}(78)=1.55, \mathrm{p}=.124, \mathrm{r}=.173$ representing a weak effect size, $95 \%$ CI $[-.48,3.91]$ ) (Table 12) indicated that there was not any significant difference between high and low anxiety groups' means on the posttest of listening proficiency. Thus the third null-hypothesis was supported.

TABLE 12

INDEPENDENT SAMPLES T-TEST: POSTTEST OF LISTENING PROFICIENCY BY ANXIETY LEVELS

\begin{tabular}{|c|c|c|c|c|c|c|c|c|}
\hline & \multicolumn{2}{|c|}{$\begin{array}{l}\text { Levene's Test for Equality of } \\
\text { Variances }\end{array}$} & \multicolumn{6}{|c|}{$\begin{array}{l}\text {-test for } \\
\text { Equality of Means }\end{array}$} \\
\hline & \multirow[t]{2}{*}{$\mathrm{F}$} & \multirow[t]{2}{*}{ Sig. } & \multirow[t]{2}{*}{$\mathrm{t}$} & \multirow{2}{*}{$\begin{array}{l}\text { Sig. (2- } \\
\text { tailed) }\end{array}$} & \multirow{2}{*}{$\begin{array}{l}\text { Mean } \\
\text { Difference }\end{array}$} & \multirow{2}{*}{$\begin{array}{l}\text { Std. Error } \\
\text { Difference }\end{array}$} & \multicolumn{2}{|c|}{$\begin{array}{l}95 \% \text { Confidence Interval of the } \\
\text { Difference }\end{array}$} \\
\hline & & & & & & & Lower & Upper \\
\hline $\begin{array}{l}\text { Equal variances } \\
\text { assumed }\end{array}$ & .211 & .648 & 1.55678 & .124 & 1.717 & 1.104 & -.480 & 3.914 \\
\hline $\begin{array}{l}\text { Equal variances not } \\
\text { assumed }\end{array}$ & & & 1.55877 .9 & 4.123 & 1.717 & 1.103 & -.478 & 3.912 \\
\hline
\end{tabular}

The results of the Levene's test $(\mathrm{F}=.211, \mathrm{p}=.648)$ (Table 12) indicated that the assumption of homogeneity of variances was met. That was why the first row of Table 12, i.e. "Equal variances assumed" was reported. 


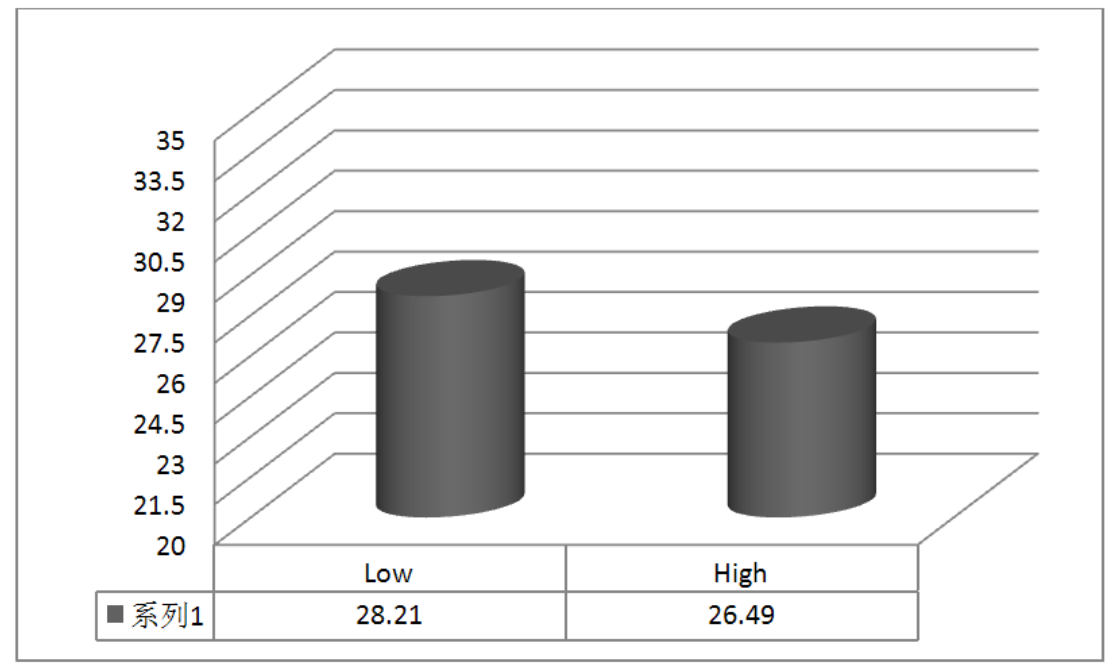

Figure 5. Means on posttest of listening proficiency by anxiety level

The Pearson correlation was run to probe any significant relationship between the subjects' performance on the posttests of listening proficiency and listening anxiety. The results $(\mathrm{r}(78)=-.26, \mathrm{p}=.020$, representing a weak to moderate effect size) indicated that there was a negative and weak to moderate relationship between the two test.

TABLE 13

\begin{tabular}{lll} 
PEARSON CORRELATION; LISTENING PERFORMANCE WITH LISTENING ANXIETY \\
\hline \multirow{3}{*}{ Post-Listening } & & Post-Anxiety \\
& Pearson Correlation & $-.260^{*}$ \\
& Sig. (2-tailed) & .020 \\
& $\mathrm{~N}$ & 80 \\
\hline
\end{tabular}

Cronbach's Alpha Reliability

The Cronbach's alpha reliability for the pretest and posttest of listening anxiety questionnaires were .51 and .73 (Table 13).

TABLE 14

RELiability Statistics; Pretest AND PostTest OF LisTening ANXIETY

\begin{tabular}{lll}
\hline & Cronbach's Alpha & N of Items \\
\hline Pretest & .514 & 22 \\
\hline Posttest & .730 & 22 \\
\hline
\end{tabular}

\section{KR-21 Reliability Indices}

The Cronbach's alpha reliability for the pretest and posttest of listening proficiency were .76 and .93 (Table 15).

TABLE 15

KR-21 ReliabiLITy InDiCES; PRETEST AND PostTest OF LiSTENING PROFICIENCY

\begin{tabular}{llllll}
\hline & $\mathrm{N}$ & Mean & Std. Deviation & Variance & KR-21 \\
\hline PreListening & 80 & 24.35 & 4.195 & 17.597 & .76 \\
PostListening & 80 & 27.33 & 4.978 & 24.779 & .93 \\
\hline
\end{tabular}

\section{Construct Validity}

A factor analysis using varimax rotation method was run to investigate the underlying construct of the pretests and posttests of listening proficiency and listening anxiety. The correlation matrix used to extract the factors should not suffer from identity and singularity. That is to say; there should be neither zero nor perfect correlations among all tests. The significant results of the Bartlett's test (Chi-square $(6)=18.68, p=.005$ ) (Table 16) indicated that the correlation matrix was an identity one, i.e. one in which there were correlations among tests.

TABLE 16

KMO AND BARTLETT'S TEST

\begin{tabular}{lll}
\hline Kaiser-Meyer-Olkin Measure of Sampling Adequacy. & .424 \\
& Approx. Chi-Square & 18.682 \\
Bartlett's Test of Sphericity & Df & 6 \\
& Sig. & .005 \\
\hline
\end{tabular}

The correlation matrix is displayed in Table 17. The determinant value of .784 was higher than the minimum acceptable value of .00001 . Based on these results it can be claimed that the correlation matrix did not suffer from singularity, i.e. perfect correlations among all variables. 
TABLE 17

CORRELATION MATRIX $^{\mathrm{a}}$

\begin{tabular}{llllll}
\hline & & PreListening & PostListening & PreAnxiety & PostAnxiety \\
\hline \multirow{4}{*}{ Correlation } & PreListening & 1.000 & .282 & -.040 & -.061 \\
& PostListening & .282 & 1.000 & .223 & -.260 \\
& PreAnxiety & -.040 & .223 & 1.000 & .092 \\
& PostAnxiety & -.061 & -.260 & .092 & 1.000 \\
\hline
\end{tabular}

Two factors were extracted as the underlying constructs of the pretests and posttests of listening proficiency and listening anxiety. This two-factor model explained 63.40 percent of the total variance (Table 18).

TABLE 18

TOTAL VARIANCE EXPLAINED

\begin{tabular}{|c|c|c|c|c|c|c|c|c|c|}
\hline \multirow[b]{2}{*}{ Component } & \multicolumn{3}{|c|}{ Initial Eigenvalues } & \multicolumn{3}{|c|}{ Extraction Sums of Squared Loadings } & \multicolumn{3}{|c|}{ Rotation Sums of Squared Loadings } \\
\hline & Total & $\%$ of Variance & Cumulative $\%$ & Total & $\%$ of Variance & Cumulative \% & Total & $\%$ of Variance & Cumulative $\%$ \\
\hline 1 & 1.435 & 35.863 & 35.863 & 1.435 & 35.863 & 35.863 & 1.404 & 35.101 & 35.101 \\
\hline 2 & 1.102 & 27.538 & 63.401 & 1.102 & 27.538 & 63.401 & 1.132 & 28.300 & 63.401 \\
\hline 3 & .931 & 23.271 & 86.672 & & & & & & \\
\hline 4 & .533 & 13.328 & 100.000 & & & & & & \\
\hline
\end{tabular}

And finally; as displayed in Table 19, the pretest (.62) and posttest (.75) of listening proficiency had significant and positive contributions to the first factor. The posttest of listening anxiety (-.66) negatively loaded on this factor, while its pretest (.92) loaded on the second factor. Since all factor loadings were higher than .50, there was no need to check the sampling adequacy assumption (KMO index in Table 16).

TABLE 19

ROTATED COMPONENT MATRIX

\begin{tabular}{lll}
\hline & \multicolumn{3}{l}{ Component } \\
\cline { 2 - 3 } & 1 & 2 \\
\hline PostListening & .757 & \\
PostAnxiety & -.660 & \\
PreListening & .629 & .929 \\
PreAnxiety & & \\
\hline
\end{tabular}

Rotated Factor Plot 1 displays the above mentioned results. The pretest of listening anxiety loaded on the positive side of the y-axis (first factor) alone. The pretest and posttest of listening proficiency loaded on the positive side of the $\mathrm{x}$-axis, while the posttest of listening anxiety fell on the negative side of the $\mathrm{x}$-axis.

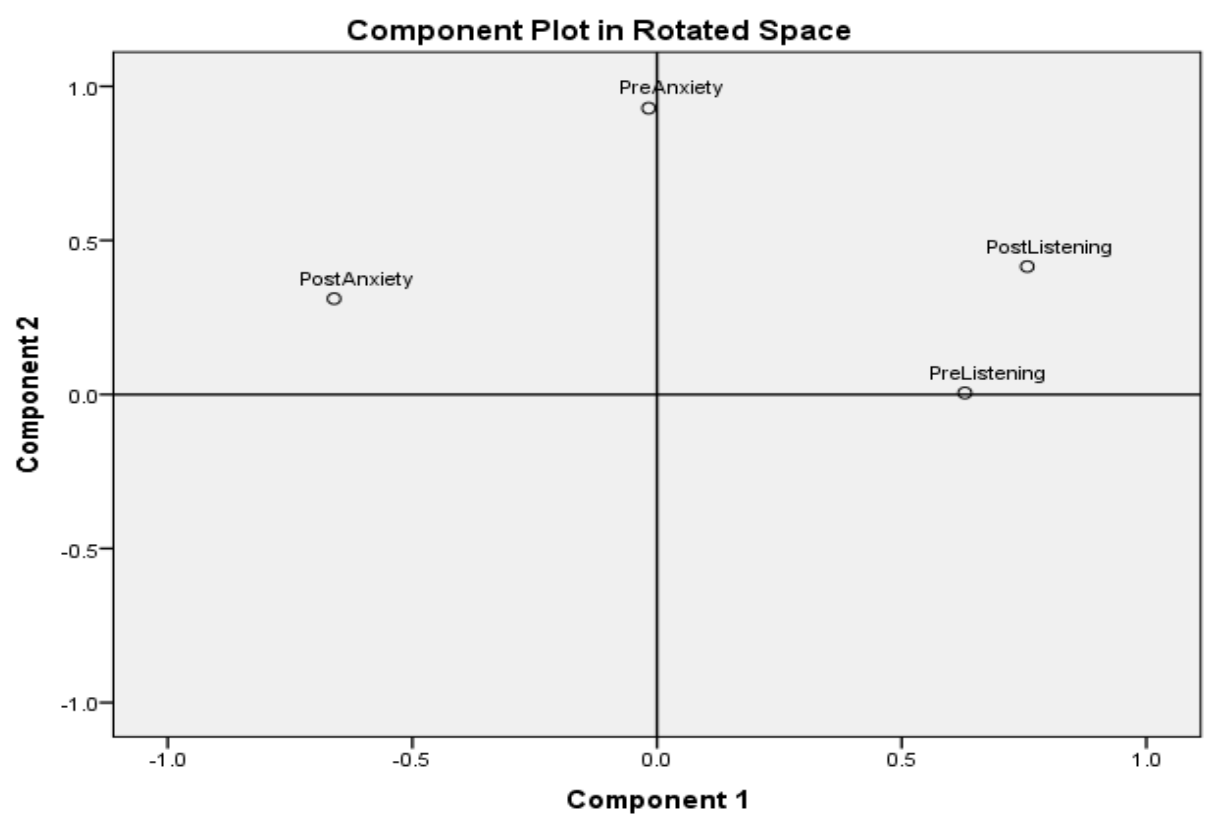

Rotated Factor Plot 1. Factor loadings in rotated space

\section{DISCUSSION AND CONCLUSION}


Before the discussion is run, a note to be minded is that our main job as teachers of foreign language listening is to assist our language learners develop procedural knowledge, i.e. knowledge about how to process spoken language with ease and automaticity(Takeuchi, Ikeda, \& Mizumoto, 2012; Khatib, \& Nikouee, 2012); that is to say, it hedges on the way to easily comprehend whatever listening input we hear ( Krashen,1988); similarly, both learners and teachers are required to make an effective use of strategy employment for developing listening performance as well as reduction of listening anxiety; put more clearly, we likewise need to devote some time teaching students some declarative knowledge (Khatib, \& Nikouee, 2012), such as comprehension skills and strategies. Therefore, the statistical and numerical data available are more in-depth discussed below.

To detail the discussion, some key issues were elaborated on: normality of the data was examined in light of the ratios of skewness and Kurtosis (See Table 1); a factor analysis was conducted so as to investigate the underlying construct of the pre-tests and post-tests of listening proficiency and listening anxiety and the result indicated a relatively perfect correlation among all the variables (See Table 15 and Table 16). Furthermore, to analyze the reliability of questionnaires associated with listening and anxiety, Cronbach Alpha indicated their being less or more reliable (See Table 12). With these in mind and required for the coming procedure, the null hypotheses are more vividly discussed below.

To start with the first problem, the learners were expected to lower their anxiety upon being instructed IELTS listening strategy; that is to say, the experimental group which was instructed strategies together with listening 10 tests expecting that this will reduce their listening anxiety was surprising. Therefore, both groups, i.e., experimental and control group, were instructed 10 tests of Cambridge IELTS (Cambridge IELTS, 2005); the former was done together with an explanation and instruction of related strategies, but the latter was performed without strategy instruction. With a view to the first null hypothesis, an independent-samples t-test was run so as to investigate the statement that IELTSListening-related strategy instruction does not reduce the IELTS-listening-related anxiety of the test takers. The hypothesis was rejected: as displayed in Table 6 , the experimental group $(\mathrm{M}=53.45, \mathrm{SD}=10.79)$ had a lower mean than the control group $(\mathrm{M}=66, \mathrm{SD}=8.51)$ on the posttest of listening anxiety. This indicates that strategy instruction did not reduce the anxiety of the experimental group, but a lack of strategy instruction for control group seems to have reduced the anxiety of the test takers. Based on this statistical finding, some possibilities are open to discussion. This result can first be accounted for by the fact that every learner is different, every context is different and every educational context is different (Kumaravadivelu, 2006). The outcome can also be related to the nature of strategy and that either strategy instruction causes the test takers to be anxious or not: This can be another research question to be further investigated.

Along approximately this line, Bensoussan (2012) has done a research into reducing anxiety associated with reading, as diametrically in association with listening we could not find any. He suggests some guidelines for coping with anxiety affecting score; However, he follows to stress that it might be disappointing as to realizing the fact that there lies test anxiety; no point worrying as it sounds natural to observe anxiety in the test takers; so, that test anxiety can more frequently make an interference with reliable evaluation of learning and that it can also frustrate the educators as well as the test takers are norm. From brief perspective, this section of the finding is in disagreement with - at least in terms of listening- whatever Bensoussan (2012) has stated: "When teachers focus on students' needs and coping strategies, anxiety can be reduced." As Bensoussan (2012) indicates, involving students in the testing process may increase their motivation and decrease anxiety in language learning: This is opposite the present research findings, so requiring further replication with big population size.

With a view to the second statement that IELTS-Listening-related strategy instruction does not develop the performance of the IELTS listening test takers, an independent-samples t-test was run (Table 9) and the experimental group $(\mathrm{M}=29.60, \mathrm{SD}=4.29)$ had a higher mean than the control group $(\mathrm{M}=25.05, \mathrm{SD}=4.59)$ on the posttest of listening proficiency. So, the experimental group after receiving IELTS-Listening-related strategy instruction significantly outperformed the control group on the posttest of listening proficiency. Thus the second null-hypothesis was rejected. This finding is in line with the research findings (e.g., Ching-Shyang Chang, \& Read, 2006; Elkhafaifi, 2005; Bachman \& Palmer, 1996; Vandergrift,2007; Vandergraft, et al. 2006) that strategy instruction affects the performance of the test takers.

Furthermore, in support of this, Gipps (1994) puts the view that a good number of construct irrelevant variances can affect the performance, so that Bachman (1995) follows to be more specific that task characteristics, such as setting, rubric, input, response, and the relationship between input and response and affect test performance. Likewise, in a confirmation to this, Weir (1990) holds the status that factors, such as background knowledge, personal experience and individual characteristics, can dramatically affect the performance.

Moving on the next statement that there is not any relationship between the performance of the group with high anxiety and a group with low anxiety on IELTS listening test, some points are argued. First, the subjects were divided into two groups of high and low anxiety based on the median score of 32 on the posttest of listening anxiety and then an independent-samples t-test was run to compare the high and low anxiety groups' performance on the posttest of listening proficiency; as it is clear in Table 11, the low anxiety group $(\mathrm{M}=28.21, \mathrm{SD}=4.86)$ had a higher mean than the high anxiety group $(\mathrm{M}=26.49, \mathrm{SD}=5.02)$ on the posttest of listening proficiency. So, based on this statistical finding, the third null hypothesis is supported. Of course, should be treated with caution because some findings indicate 
that high anxiety and low anxiety can affect the performance of the test takers (e.g., Matsudaa, \& Gobel, 2004; Suleimenova, 2013; Khattack, Jamshed, Baig, 2011). The finding associated with this section of the thesis is opposite what Saito and Samimy (1996) state in connection with the reality that anxiety can dramatically affect the performance of the language learners and test takers. The results of their study indicated that the performance of the language learners with a view to the level of their anxiety as well as the level of their language, i.e., either they are elementary, pre-intermediate, intermediate or upper-intermediate, differed. Their findings finally displayed that anxiety is the best predictor of the performance of the language learners.

Finally, the fourth problem that there is not any significant relationship between the performance of the test takers on IELTS listening and their anxiety level is tackled and discussed. Previous findings have indicated that there is a relationship between performance on listening and anxiety level. But the present study indicated a negative and weak relationship between the two, so he null hypothesis is rejected; of course, the disconfirmation of the hypothesis should be considered cautiously due to the weak and moderate effect size (See Table 13).

This paper has made an attempt to provide pedagogical insights into promoting autonomous listening development outside the classroom through employing the effect of strategy use as well as anxiety tackling strategies; in effect, these all help the learners enhance their metacognitive capacity and cope with the problems of IELTS listening comprehension. However the current research did not display the possible relationship between anxiety and listening performance, thee lies a vast number of research supporting the effect of anxiety on language learning and the effect of anxiety on listening needs further research. The nature of anxiety is itself debilitative, so that high level of anxiety can possibly lead to low performance in the foreign language, but in the case of listening, the present research indicated no effect and more replication needs to be done.

\section{REFERENCES}

[1] Aryadoust, V. (2013). Building a validity argument for a listening test of academic proficiency. New Castle: Cambridge Scholars Publishing.

[2] Bachman, L. F. (1995). Fundamental Consideration in language testing. Oxford: Oxford University Press.

[3] Bachman, L. F. \& Palmer, A.S. (2000). Language testing in practice. Oxford: Oxford University Press.

[4] Bensoussan, M. (2012). Alleviating Test Anxiety for Students of Advanced Reading

[5] Cambridge University. (2005). Cambridge IELTS 4: Examination Papers from the University of Cambridge ESOL Examinations. Cambridge: Cambridge University Press.

[6] Carter,R., \& Nunan, D. (2001). The Cambridge Guide to Teaching English to Speakers of Other Languages. Cambridge: Cambridge University Press.

[7] Cassady, J. C., \& Johnson, R.E. (2002). Cognitive Test Anxiety and Academic Performance. Contemporary Educational Psychology, 27, 270-295

[8] Ching-Shyang Chang,A., \& Read,J. (2006).The effects of listening support on the listening performance of EFL Learners. TESOL Quarterly, 40 (2), 375-397.

[9] Cross, J. (2009). Effects of listening strategy instruction on news videotext comprehension. Language Teaching Research, 13(2), 151-176.

[10] Dunkel, P. (1991). Listening in the Native and Second/Foreign Language: Toward an Integration of Research and Practice. TESOL Quarterly, 25( 3), 431-457

[11] Elkhafaifi, H. (2005). Listening Comprehension and Anxiety in the Arabic Language Classroom. The Modern Language Journal, 89 (2) 206-220.

[12] Gipps, C.V. (1994). Beyond Testing: towards a theory of educational assessment. London: Palmer Press.

[13] Goh, C. (2008). Metacognitive Instruction for Second Language Listening Development: Theory, Practice and Research Implications. RELC Journal, 39(2) 188-213.

[14] IELTS Annual Review. (2007). The World Speaks IELTS. http://www.ielts-russia.ru/images/newsletter/4.pdf Retrieved on $2016,10,15$.

[15] In'nami, Y. (2006). The effects of test anxiety on listening test performance. System, 34, 317-340.

[16] Issitt, S. (2007). Improving Scores on IELTS Speaking Test. ELT Journal, 62 (2).

[17] Jakeman, V., McDowell, C. (2006). Action Plan for IELTS. Cambridge: Cambridge University Press.

[18] Khatib, M., \& Nikouee, M. (2012). Planned focus on form: Automatization of Procedural Knowledge. RELC Journal, 43(2), $187-201$.

[19] Khattack, Z. I., Jamshed, T., \& Baig, M.N. (2011). An Investigation into the causes of English Language Learning Anxiety in Students at AWKUM. Social and Behavioral Science, 15(1),1600-1604.

[20] Krashen, S.D. (1988). Second Language Acquisition and Second Language Learning. Prentice - Hall: New York.

[21] Kumaravadivelu, B. (2006). Understanding Language Teaching: From Method to Theory. London: Taylor \& Francis Publications

[22] Lindsay, C. \& Knight, P. (2006). Learning and Teaching English. Oxford: Oxford University Press.

[23] Liu, M. (2006). Anxiety in Chinese EFL students at different proficiency levels. System, 34,301-316.

[24] Lynch, T. (2011). Academic listening in the 21st century: Reviewing a decade of research. Journal of English for Academic Purposes, 10, 79-88.

[25] Matsudaa, S.,\& Gobel, P. (2004). Anxiety and predictors of performance in the foreign language classroom. System, 32(1), 2136

[26] McCarter, S. (2006). Tips for IELTS: A Must-Have for All IELTS Candidates. Oxford: Macmillan. 
[27] Moyer, A. (2006). Language contact and confidence in second language listening comprehension: A pilot study of advanced learners of German. Foreign Language Annals, 39(2), 255-275.

[28] Richards, J.C., \& Renandya, W.A. (2002). Methodology in language teaching: An anthology of current practice. Cambridge: Cambridge University Press.

[29] Saito, Y., \& Samimy, K. (1996). Foreign Language Anxiety and Language Performance: A Study of Learner Anxiety in Beginning, Intermediate, and Advanced-Level College Students of Japanese. Foreign Language Annals, 29(2), 239-249

[30] Suleimenova, Z. (2013). Speaking Anxiety in a Foreign Language Classroom Kazakhastan. Social and Behavioral Sciences, 93(21), 1860-1868

[31] Swan,M. (2008).Talking Sense about Learning Strategies. RELC Journal, 39(2) 262-273

[32] Takeuchi, O., Ikeda, M., \& Mizumoto, A. (2012).Reading aloud activity in L2 and cerebral activation. RELC Journal, 43(2), 151-167.

[33] Vandergrift, L. (2007). Recent developments in second and foreign language listening comprehension research. Language Teaching, 40, 191-210.

[34] Vandergrift, L., \& Tafaghodtari, M. H. (2010). Teaching L2 learners how to listen does make a difference: An empirical study. Language Learning, 60, 470-497.

[35] Weir, C. J. (1990). Communicative language testing. London: Prentice-Hall, Inc.

[36] Xu, F. (2011). Anxiety in EFL listening comprehension. Theory and Practice in Language Studies 1(2), 1709-1717

[37] Yeldham,M., \& Gruba, P. (2014). Toward an instructional approach to developing interactive second language listening. Language Teaching Research, 18(1), 33-53.

Amir Reza Nemat Tabrizi, PhD in TEFL, is a faculty member at Tabriz Payame Nour University; he has published a good number of papers in the field of English language teaching and assessment. Furthermore, he has presented articles in national and international conferences.

Mahnaz Ranjbar is an MA student at Islamic Azad University, Ahar. She has also some published and presented articles. 